\section{Black paper for science}

SIR - The publication of the government's White Paper on science and technology has provided opportunities for serious debate about the status of science in the United Kingdom. Most of the Office of Science and Technology (OST) proposals have been welcomed and an innocuous sense of relief now pervades the scientific community.

For myself, the comfort afforded to the OST paper by the guardians of British science rests like a pea beneath the mattress of our science base. I am a young and naive research scientist fortunate enough to have been 'turned-on' to science. For me science is 'a way of life', and satisfaction comes from the possibility that my research may contribute to man's knowledge. The fact that I feel uneasy and out of date with such an appreciation of science is due to recent unremarkable changes in the philosophy of science, changes that have been given an official credibility in the government's paper.

My interpretation of the White Paper seems to be at odds with most of what has been said or written so far and might be summarized as follows.

Britain is in recession. The government is unhappy. Industry is unhappy. Each would like to blame the other. Each would like the other to help to improve the economic reality. Both have, at last, agreed that a strong industrial/ manufacturing base is essential to economic recovery. Manufacturing and industrial competitiveness have been in decline for many decades and the government seems to have pinned the blame for this decline firmly upon academic research. We are told that a lack of direction in academic scientific research, particularly as it applies to industry, is chiefly responsible. The White Paper proposes to remedy this through the implementation of several inherently damaging and prospectively irreparable schemes.

(1) Industry has controlled and continues to control most spending on scientific research and development in the United Kingdom. The present balance of payments speaks volumes on their use of these funds and yet the government believes that industry should now be given the opportunity to influence how academic institutions, through the research councils, spend the remaining part of the research and development budget. (2) Basic science is to be gradually replaced by foresight, a transition that will greatly expedite the ability of industry to improve the 'value' of academic research. Foresight, no doubt, will be taught as one of the many new master's degrees which, in the government's proposal, are introduced as a more cost-effective alternative to the doctorate of philosophy. This should have been easy to predict in the light of the closures of university philosophy departments during the past $10-20$ years.

I am not suggesting that research in higher education and government institutes should not be subject to change. Indeed, it is crying out for change, particularly in the career structure of research scientists. Accountability, when well founded, can only contribute towards research excellence, but basic science in universities and research institutes should not be made to account for the present slump in the industrial and manufacturing base of the nation. Basic science in Britain is still exceptional and industry and the government must decide how to make the most effective use of this asset and not change the science base to suit its shortterm needs. If I were to be the first graduate of the government's School of Foresight and I were to base my dissertation on the White Paper, then I would rightly fear not only for my future as a research scientist but more importantly for the future of basic science in the United Kingdom.

\section{Christopher Exley}

Department of Chemistry,

Keele University,

Keele, Staffordshire ST5 5BG, UK

\section{Human goodness?}

SIR - Brian Josephson's concept of religion as an attempt to maximize "human goodness" (Nature 362, 583; 1993) is naive and ignores everything we know about religion. The sine qua non of any religion is the existence of supernatural forces. On this point the validity of religion stands or falls; genetics is simply irrelevant.

Of the known religions, that of the Aztecs perhaps best illustrates the place of "human goodness" in religion. The Aztecs' religion involved human sacrifice, as did the religions of Central America and Mexico that preceded them. The victim, often a prisoner of war, was spread-eagled on the altar by four priests, while a fifth cut his chest open with an obsidian knife and took out the heart. The victim's head was then severed and put on display in front of the temple while the rest of his body was butchered for meat, to be eaten by the priests or the soldiers who had captured the victim.

This was not a small operation, as Bernal Díaz del Castillo, a conquistador who fought with Cortéz, observed: "I remember that in the plaza where their oratories stood, there were piles of human skulls so regularly arranged that one could count them, and I estimated them at more than a hundred thousand. I repeat again that there were more than one hundred thousand of them. And in another part of the plaza there were so many piles of dead men's thigh bones that one could not count them; there was also a large number of skulls strung between beams of wood, and three priests who had charge of these bones and skulls were guarding them. We had occasion to see many such things as we penetrated into the country for the same custom was observed in all towns, including those of Tlaxcala." (The Discovery and Conquest of Mexico, Farrar, Straus and Cudahy, 1956, p. 119).

In the Old World, human sacrifice was also a part of the religion of the Carthaginians, who took it with them wherever they established colonies (A. Moscati, Scientific American, February 1975, 80 81 ). In their case the victims were female children, brought to the temple by their parents to be immolated in the temple oven or outdoor burning ground known as a tophet. Had Rome lost the Punic Wars (had Hannibal sacked Rome after Cannae!) theirs would probably have become the established religion of the Ancient World.

\section{Arno Arrak}

5 Chatham Place,

Dix Hills, New York 11746, USA

\section{Rustum Roy}

SIR - The Penn State chemistry faculty wishes to express its concern about a recent incident involving an attack by Rustum Roy, a professor of the solid state, on Professor Patricia Bianconi, a faculty member of our department. Bianconi published in Nature 1 a carefully referenced paper clearly stating the history of this area, which led to her successful demonstration that ordered CdS crystals can be precipitated in an organic polymer network.

Roy felt that some earlier work ${ }^{2}$ from his laboratory should have been cited. Rather than directly contacting Bianconi, he submitted letters to journals and funding agencies. We, as colleagues of Bianconi and as scientists ourselves, were dismayed by this course of action. Moreover, on carefully reading both Bianconi's and Roy's articles, we do not feel she slighted him by not referencing his article.

We are delighted that a public apology has now been offered by Roy ${ }^{3}$. It is time to close this issue and allow a promising young scientist and colleague to get on with her scholarly work.

Andrew G. Ewing

on behalf of 32 members

of the chemistry faculty,

Pennsylvania State University,

University Park, Pennsylvania 16802, USA

1. Nature 349, 315 (1991).

2. Mater. Lett. 2, 245 (1984)

3. Nature 359, 472 (1992); Science 258, 874 (1992) 